\title{
支部委員会報告
}

「第 6 回 次世代の臨床外科医のための特別セミナー」報告

（支部委員会副委員長 小西 敏郎）

2013年から始まった「次世代の臨床外科医のための特別セミナー」は, 本年は 2 月 3 日 (土)・4 日 (日) に, 例年と同じ東京・品川のグランドプリンスホテル新高輪において行われた。この特別セミナーは, 本学会の支部活動の活性化を図りながら, 多忙な臨床現場で日夜奮闘する若手医師に, 2 日間広い領域 にわたる最新の外科臨床の諸問題を学修してもらうことで, 外科診療への意欲を増し, そして本学会へ の入会者も増加することを期待して開催している.

本年の参加資格は, これまでと同様に, 本学会会員で1)各道府県支部から 3 名, (2)原則として40歳未 満の若手医師, (3)できるだけ女性を 1 名含める, (4)卒後 2 年以内の初期研修中で外科進路を考慮中の学 会未入会者を 1 名含めてもよい, とした. また本年は, 開始以来 5 年経過するので, (5)本セミナーに未 参加の支部長は， 3 名の枠内のなかで, できるだけご参加ください. そして(6)公募ビデオの提出者の中 より選出された若手の先生は，3名のほかに追加で出席していただいても結構です，とさせていただいた．

本年のセミナーには全国の全46支部から，4名の支部長を含めた 122 名の医師が参加した．学会役員・ 演者を含めると, 出席者は過去最高の合計159名で, 女性外科医も34名とこれまでの最多の参加であった. また 3 年前から参加可としている進路決定前の研修医の参加は, 本年は 21 名 ( 3 年前 9 名, 2 年前 14 名, 昨年18名）と増加し，これまででもっとも多くの非会員の研修医が各支部からの推薦で参加した。ちな みにこれら非会員の研修医は, 3 年前は 9 名のうち 7 名が, 2 年前の 14 名のうち 8 名が, 昨年は 18 名の うち 10 名が, セミナー参加後に本学会に入会している. 進路未決定の研修医は, 本セミナーの参加後に 61\%が外科医の道を選んだことになるので, 本セミナーは外科医の増加に大いに貢献しているといえる.

初日は午後 3 時に開会し, 特別コメンテータとしてお招きした中井美穂アナウンサーの参加で, 古川 俊治先生（慶應義塾大・参議院議員）の「日本のこれからの医療政策」の講義, ついで野村幸世先生（東 京大学）の「母として, 外科医の妻としての女性消化器外科医」の二つの講演が行われた.

その後, 本年で 4 年目となる内視鏡下手術のビデオ提示によるパネルディスカッション「教わる者の 心・教える者の心」が早川哲史先生（刚谷豊田総合病院）の企画および総合司会で行われた. このパネ ルでは 2 年前から全国の支部に若手医師による手術ビデオ提示を公募で依頼しており, 本年は肺癌, 胃 癌, 大腸癌, 肝癌の 4 部門の手術ビデオを募集した. 短期間の公募期間であるが, 全国から合計 27 名（肺 2 , 胃 4 , 大腸 16 , 肝 5 ) とこれまでの最多の応募があった. 事前に, 岩崎正之 (東海大学), 宇山一 朗 (藤田保健衛生大学), 坂井義治 (京都大学), 金子弘真 (東邦大学) の 4 名のコメンテー夕により, 各部門からそれぞれ優秀ビデオを選出していただいた。 パネルでは, 選ばれた 4 名の演者が, 教わる者 の立場から内視鏡手術のビデオ提示を行ったあとに, 教える者の立場の 4 人のコメンテータから指導や 質問があり，そして模範ビデオを提示しながら質疑・討論が行われた４人のコメンテータと総合司会 の早川先生の鋭く厳しい指摘やフロアーからの質疑・発言は, 普段の学会ではなかなか聞けない本音の 意見ばかりであり，ビデオ発表者だけでなく会場の若手外科医にも大いに参考になった.

夜の懇親会では, 学会役員・支部長も含めて世代・地域に関係なく,「くじ引き」で完璧にシャッフ ルされた席のテーブルで, 大いに親睦を深めることができたようである. 私のテーブルは隣の早川先生 とあと 1 名以外は, なぜか全員若手女性外科医であったが, 羡ましがる他の役員から不満がでなかった のも, 公平感のある「くじ引き」のおかげ. 例年ホテルの御好意で持ち込む破格值の美味なイタリア赤 
ワインの効果に加えて, 女性だけでなく男性外科医をも発奮させる中井美穂アナや 2 日目のトップ演者 でご自分の講演を前宣伝する大木教授のスピーチなどのおかげで, 会場も大いに盛り上がり, 大変有意 義な情報交換の場となった，ちなみに，私のテーブルの全員が，私と早川先生の名前も所属も存在もま ったく知らない若手女性外科医だったので, 二人は食事も忘れて必死になって, 外科医としての経験談 や自慢話で外科医生活の魅力を語った 2 時間のテーブル席であった。 なお懇親会では, パネルデイスカ ッションでのビデオプレゼンターおよびコメンテータが表彰された.

二日目は, 毎年大好評で要望の多い「私が理想とする外科医」の講演で, まず大木隆生先生（東京慈 恵会医科大), そして大分県支部長の上尾裕昭先生 (うえお乳腺外科), 最後は塩崎均先生（近畿大学） から，それぞれご自分の歩んできた外科医としての軌跡・信条の紹介があった．３人の先生は，専門分 野や活動経歴がまったく異なるだけでなく, 人生哲学も, そして講演の話し方まで, それぞれ独特の個 性的な三者三様のお話しであり，若手外科医には大いなる刺激となる講演をいただいた.

本年のセミナーの最後は, 深柄和彦先生 (東京大学) から「外科医が知っておくべき栄養学」の講演 が, ランチョンセミナーとして行われた.

本年もまた, 参加者全員が, 今後の外科臨床にむけて心地よい活力となる刺激を受け, 全身にエネル ギーをチャージできた特別セミナーであったと思われる. 本年参加した 21 名の進路未決定の医師達の全 員が，2 日間のセミナーを受講することで, 夢と希望をもって外科医の道を選んでほしい, と願いなが ら本会を終了した。

なお，すべての講演は学会HPで閲覧できるので，どうぞご利用いただきたい.

次回の第 7 回は, 2019年 2 月 2 日（土） 3 日（日）の開催予定である.

期日：2018年 2 月 3 日（土）・4日（日）

場所：東京 品川

グランドプリンスホテル新高輪

プログラム

2 月 3 日（土）午後 3 時から

1. 跡見 裕 会長挨拶

2. 15 時05分一15時55分

講演 (1)「日本のこれからの医療政策」

古川 俊治（慶應義塾大学・参議院議員）

司会山口 俊晴 (がん研有明病院)

3. 15 時 55 分一 16 時 45 分

講演(2)「母として, 外科医の妻としての女性消化器外科医」

野村 幸世（東京大学）

司会國土 典宏（国立国際医療研究センター）

4. 16 時50分一18時50分

手術手技パネル—「教わる者の心・教える者の心」

「肺癌・胃癌 - 大腸癌 ・肝癌」 
総合司会早川 哲史（刈谷豊田総合病院）

コメンテーター

1. 肺 癌岩㟝 正之（東海大学）

2. 胃 癌宇山一朗 (藤田保健衛生大学)

3. 大腸癌坂井 義治 (京都大学)

4. 肝癌金子 弘真 (東邦大学)

ビデオ発表者

1. 肺 癌 川瀬 晃和 (浜松医科大学外科学第 1 講座呼吸器外科)

2. 胃 癌新野 直樹 (大阪労災病院外科)

3. 大腸癌根岸 宏行 (聖マリアンナ医科大学消化器 - 一般外科)

4. 肝癌酒井健司 (JCHO大阪病院)

5. 19時より 懇親会 司会 小西 敏郎（東京医療保健大学）

*初日の特別コメンテーター 中井 美穂アナウンサー

2 月 4 日（日）午前 9 時から

6. 9 時一11時 30 分「私が理想とする外科医」
(1)大木 隆生 (東京慈恵会医科大学)
9 時一 9 時50分

司会松原 久裕 (千葉大学)

(2)上尾 裕昭 （うえお乳腺外科 大分県支部長） 9 時50分一 10 時40分

司会 矢永 勝彦 (東京慈恵会医科大学)

(3)塩㟝 均 (近畿大学) 10時40分一11時30分

司会方代 恭嗣（東京山手メディカルセンター）

7. 11時40分一12時30分 ランチョンセミナー

「外科医が知っておくべき栄養学」深柄 和彦 (東京大学)

司会窪田 敬一( 獨協医科大学)

8. 12時30分 閉会の挨拶 炭山 嘉伸 支部委員会委員長

(終了 12時40分) 


\section{講演1 日本のこれからの医療政策}

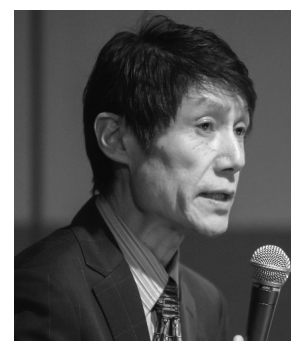

演者：古川 俊治先生

(参議院議員)

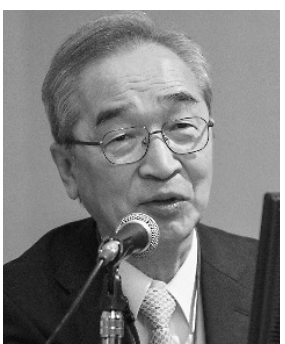

司会：山口 俊晴先生

(副会長)

日本では，世界的にも突出した水準で公的債務が累積を続ける財政状況の中で，世界一の高齢化が進 む状況となっている．団塊の世代が75歳となる2025年に向かって増加する医療・介護ニーズに対応する とともに，医療・介護提供体制を出来る限り効率化していく必要がある。「医療から介護へ」「治す医療 から治し支える医療へ」「入院・施設から外来・在宅へ」という政策動向の下で, 地域における医療機 関の機能分化と連携が推進されている. 高額な医療技術も問題となってきており, 今後は, 外科医療技 術等についても，公的医療保険における取り扱いに関しては，費用対効果が考慮されざるを得ないであ ろう。都市と地方の間や, 診療科間の医師偏在も大きな問題となっており, 2018年の通常国会では, 地 域医療対策協議会と知事の権限を強化する医療法・医師法の改正案が審議されている。また, 長時間労 働是正のための「医師の働き方改革」の議論も開始されているが，医師の業務の特殊姓や地域医療への 影響を十分に考慮した制度構築が課題である。

\section{講演２母としての，外科医の妻としての女性消化器外科医}

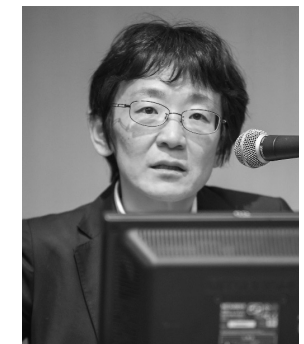

演者：野村 幸世先生 (東京大学)

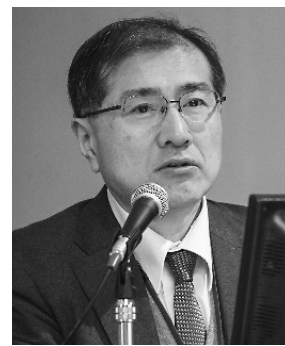

司会：國土 典宏先生 (常任幹事)

表題のような立場である私から，若いこれからの外科医の先生方へのメッセージを語らせていただき ました，女性外科医が増加し，日本が少子化する現状の中で，女性外科医には是非，若いうちに出産を され，かつ，仕事も常勤をお続けいただきたいことを抎伝えしました．男性外科医には，パートナーと なる女性と同様かそれ以上に家事，育児に関わっていってほしいことをお伝えしました.

その鍵となる方策には教育の重要性をあげました，子供の教育では，母親が常勤を継続したほうが子 供の精神状態が安定しています。また，職場では技術の継承だけではなく，メンタリングが重要で，若 い先生方もすでにさらに若い方のメンターとなりうることをお話ししました．さらに，この教育により， 男女ともに仕事が効率化でき，この余裕で家庭運営を実行することも可能となります．家庭運営は楽し いことなので，ぜひ，皆さんに経験していただきたいと思います. 


\section{手術手技パネルー「教わる者の心・教える者の心」}

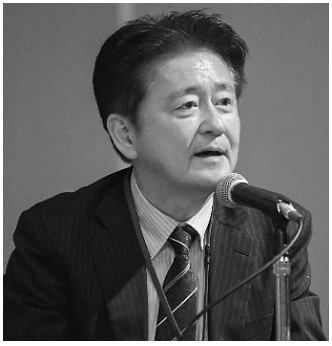

司会：早川 哲史先生

(幹事)

\section{【総合司会】}

今回の手術手技パネルでは,「教わる者の心・教える者の心」をテーマに 企画させていただきました，代表的な疾患である肺癌, 胃癌, 大腸癌, 肝癌 をテーマに取り上げ，発表演者の先生方には，まさに今学びたい内容を中心 に 7 分間の手術ビデオと「教わる者の心」についてご発表いただきました.「教 える者の心」としての講師は, 肺癌では東海大学呼吸器外科の岩㟝正之先生, 胃癌では藤田保健衛生大学総合消化器外科の宇山一朗先生, 大腸癌では京都 大学消化管外科の坂井義治先生, 肝臟癌では東邦大学医学部外科の金子弘真 先生にお願いし，各演者が供覧したビデオに対するコメントをいただき，そ の後に各領域において忘れてはならない重要なポイントなどのご講演をして いただきました。「次世代の臨床外科医のための特別セミナー」にふさわしい演題が各領域の講師によ り選出され, 参加された若い先生方や研修医の皆様にとって未来に向けて何かを持ち帰っていただくこ とができた有意義なセミナーであったと思います.



コメンテーター: 岩㠃 正之先生 (東海大学)

\section{【肺 癌】}

今回，呼吸器外科医であれば必ず習得しておかなければならない手技では あるものの, 日常的にはそれほど遭遇しない大切な手術手技である心膜切開・ 心膜内操作を取り上げました。浜松医科大学外科学第 1 講座呼吸器外科の川 瀬晃和先生が応募された心膜内での主肺動脈剥離と処理の映像は，極めて明 瞭, 的確な操作が記録されており, 特に心膜と心囊の解剖や心囊内の大血管 剥離操作を安全かつ大胆に進めていく映像は, 指導される先生の熱い想いを 感じさせる手術手技でした。膜の解剖は案外複雑で，実際には壁側胸膜・ 線維性心膜・漿膜性心膜壁側板を切開して心囊内に至っているのですが，日 常的にはこの複雑な解剖を一気に剥離鉗子で進めながら大血管の处理を行っ ているわけです。また, 心膜切開時に心停止に至ることもあり, Marshall勒帯に注意する必要があり ます．胎生期の遺残を注意することが安全な手術に繋がり，その意味でこのビデオを採用させて頂きま した.

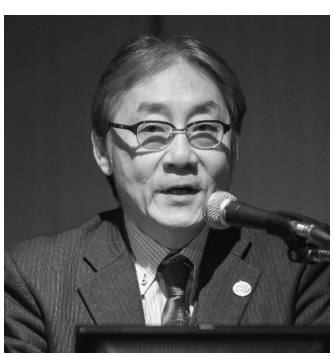

コメンテーター: 宇山 一朗先生 (藤田保健衛生大学)

\section{【胃 癌】}

1992年に北野正剛先生が本邦初のリンパ節郭清を伴う腹腔鏡下胃癌手術を 施行して以来, 同手術は進化発展してきた。私は1998年の第70回日本胃癌学 会で初めて腹腔鏡下膵上縁リンパ節郭清を報告し，その後，1999年に腹腔鏡 下 D2 郭清の手術を報告した. 1999年から2000年前半にD2 リンパ節郭清は 開腹術および腹腹腔鏡の熟練医が行えば腔鏡下に十分施行な術式であった。 この術式を支えていた事項は, 郭清の理論ではなく, “正しい手術器具の使 い方”であったと考え, 腹腔鏡手術に扔ける器具の正しい, 安全な使い方を 動画を交えて解説した，その後，2006年以降に“outermost layer oriented medial approach”という概念が出現し, 現在の普遍性があり, かつ非常に安全 な腹膛鏡リンパ節郭清の手技が確立したので，その手技を意義と詳細を解説した。 


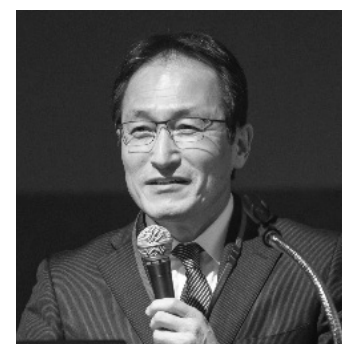

コメンテーター : 坂井 義治先生 (京都大学)

\section{【大腸癌】}

16名の応募の中から聖マリアンナ医科大学 根岸宏行先生を指名させて頂 きました．先生は「教わる者の心」として“手術中の心の叫び”を網羅して くれましたが，誰しも修練中には経験することと思います．応募者全員の考 えをまとめると以下のようになります：復習が最も重要，チームで手技の言 語化（見える化）により共通認識の形成と定型化を目指すこと，特にランド マーク・剥離層・郭清範囲の共通認識が重要，実践は模範となる手技をコピ ー/トレースすること．教える者として私の考えを提示しました．手術の基 本原則：1）剥離層の概念と認識：「筋膜」とは全身の臟器・組織を包む線 維性結合組織であり，「剥離」とはこれを切離すること。2）視野展開にお ける静と動：助手と術者の左手による「面」を形成する視野展開，その中で動くのは術者の右手のみ. 応募ビデオのほとんどは技術認定試験合格レベルに達しており，若き外科医の熟達の速度に驚嘆しまし た.

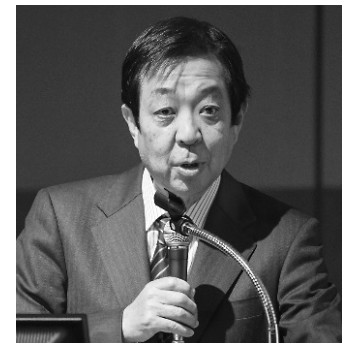

コメンテーター: 金子 弘真先生 (常任幹事)

\section{【肝 癌】}

肝癌に対する内視鏡外科肝切除術の応募ビデオは 5 編であった．次世代の 外科医のためと言うタイトルから難易度の低い肝表在の肝部分切除術を選択 し JCHO大阪病院の酒井健司先生には出血の少ないビデオを供覧していただ き，腹腔鏡下肝切除術の基本的な考え方を教えるものの心として述べさせて もらった. 腹腔鏡下肝切除を完遂するための最も重要な点は出血制御であり, とくに開腹術に比し腹腔鏡下手術の劣る点は，不慮の出血に対する対応であ る。この課題に対する肝切除への腹腔鏡用手術器具の開発改良は，本術式の 安全性を確保・追求するうえで欠くことのできない要素である．肝臟実質切 離に際しては比較的脈管の少ない浅い層とグリソンや太い肝静脈が存在する 深い層を意識した手技や器具の選択のもと手術を進める。重要なことはそれぞれの手術機器の特性をよ く理解して使用することである。また, 腹腔鏡下肝切除は通常の開腹手術に比心゙難易度は高く, その手 技の習得により多くの時間を要し, 強くラーニングカーブが関与している. 症例ごとに外科医自身の手 術技量を考慮して，慎重に適応を検討する必要がある. 


\section{講演「私が理想とする外科医」}

\section{講演(1) 私の目指す理想の外科医}

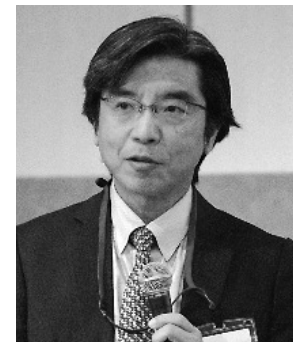

演者：大木 隆生先生 (東京慈恵会医科大学)

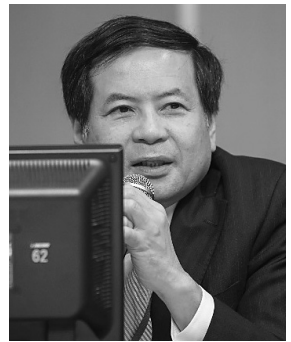

司会：松原 久裕先生

(常任幹事)

患者の命を預かり，体にメスを入れる以上，日ごろから鍛錬しメス裁きや系結びを含め手術巧者であ ること，常に平常心を保てる心を持つこと，価值のある発見をした際は速やかに論文化して世に発信す ることは必要条件である。加えて以下の要素が理想として十分条件である。すなわち絶対成功する手術 は存在しないので, 常に合併症を念頭に患者・医師信頼関係を構築する必要があり, 私はそのために外 来での身だしなみ, 触診を含む入念な診察, そして紹介医への返信には原稿用紙 6 枚程度例外なく同日 に書きそれを患者にも郵送している. IC 取得に際してはアリバイ作りにならないように配慮すべきで ある．完成された手術は存在しないとの考えに基づき，先人から受け継いだ技術に創意工夫を加えて後 進にタスキを渡す. 国際化, 若手啓発・育成も欠かせない要素である. 最後に自身の健康管理に留意し, 家族を大切にすることも重要であろう。私はまだ理想の外科医への道半ばであり今後も精進したい.

\section{講演(2)＼cjkstart私の理想とする外科医}

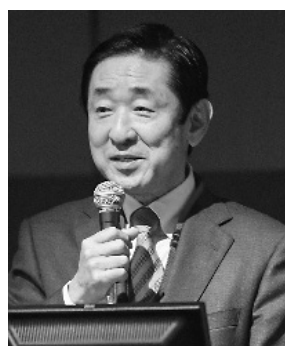

演者：上尾 裕昭先生

(うえ拈乳腺外科, 幹事)

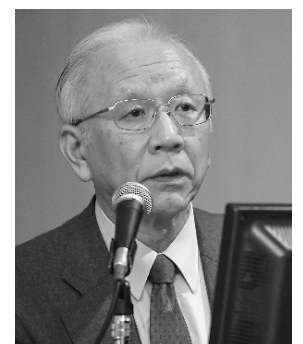

司会 : 矢永 勝彦先生 (常任幹事)

「理想の外科医を求めて」という立場から, 次の 3 つのサブテーマにおける自身の経験を紹介し, 若 手外科医へメッセージを託した.

（1）乳がん診療のパラダイムシフト：大きく変貌した乳癌の診断・手術・薬物療法・乳房再建の歴史 を紹介するとともに，外科医自身のQOLにも配虑すべき時代の到来を予告した。（2）臨床外科医のリ サーチマインド：外科医人生の中で“探求する気持ち”を持ち続けることの楽しさを, 自身の 4 つの工 ピソードを交えて紹介. 例えば, 若い頃の微小リンパ節転移の研究は15年後の OSNA 導入, そして現 在（20年後）の蛍光診断へと繋がった。また，35年前の脂肪幹細胞分化の基礎的研究は，現在の脂肪幹 
細胞移植の臨床応用に繋がっている。（3）NBM（Narrative Based Medicine）：進行両側乳癌に対し て化学療法後に広範囲切除＋皮膚移植を施行した40歳代女性・家族と医療スタッフとの交流を紹介し, 外科チームにしかできないNBM（やり甲斐）のあることを強調した.

\section{講演(3 理想の外科医を求めて}
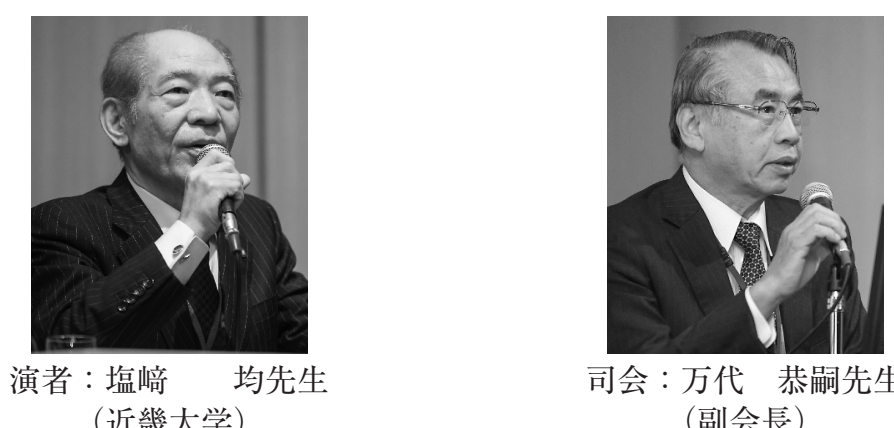

司会 : 万代 恭嗣先生

(副会長)

患者さんとこころの繋がらない医療ほど，外科医にとって虚しいことはありません．患者さんのここ ろを掴むためには，しっかりとした姿勢と努力をすることが必要です.

1 ，医師である前に一人の人間であれ。

（医師が有利な立場であることを忘れず，いつも謙虚に，患者さんのことを考えること）

2 ，患者さんを好きになれ，自分を好きになれ。

（患者さんを好きになれば自然に患者さんのためになることを考えるようになる）

3，どんなことがあっても諦め手術はするな.

（納得できなければ，議論する位の気力・体力をもて）

4 , 忙しさと楽しさは相反するものではない.

(どんなに忙しくても楽しむ心を忘れるな)

5 ，身だしなみはきちっとする，元気よく挨拶する．朝 8 時までには仕事を始める.

これは外科医としての私の心構えです。 日々の診療の中で, 悩み苦しむことで, 人として患者さんに 対峙できる喜びを勝ち取ろう。 


\section{ランチョンセミナー「外科医が知っておくべき栄養学」}

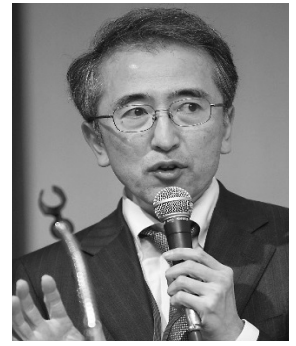

演者：深柄 和彦先生 (東京大学)

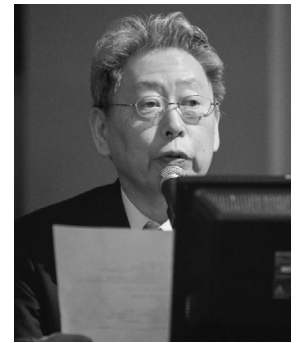

演者：窪田 敬一先生

(獨協医科大学)

残念ながら日本の医学生の大半は学生時代に臨床栄養の講義を受ける機会がないまま医師になる。そ して, さらに残念なことに, 医師になってからも臨床栄養の勉強をする機会がないことが多い. しかし, 外科患者の術後経過, 長期予後改善に適切な栄養療法が大きく貢献することを外科医は認識すべきであ る．外科患者は，その疾患がゆえに長期間にわたって十分な食事を摂取することができず，また，術後 も栄養摂取が不十分なことがしばしばである. 栄養摂取・投与不足に伴う低栄養状態は, 患者の正常な 生体反応を障害し, 感染防御能の低下, 創傷治癒の遅延, 筋肉喪失によるADLの大幅な低下, 臟器障 害の増悪を招く. 腸管を使った栄養管理は生体の感染防御能を高めるので, 経口摂取が不十分であれば, まずそれを増やす工夫を，経口摂取が難しければ経腸栄養を考慮すべきである，経腸栄養で十分な栄養 を投与できない場合は，静脈栄養の併用をためらってはいけない. 